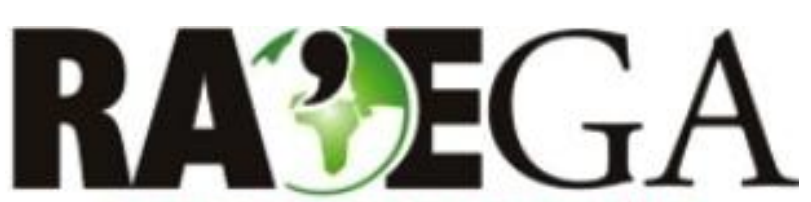

O ESPACYO GEOGRÁFICO EM ANÁLISE

\title{
AS PINTURAS RUPESTRES NA REGIÃO DE PIRAÍ DA SERRA, PARANÁ
}

\section{THE ROCK PAINTINGS IN THE REGION OF PIRAI DA SERRA, PARANA}

\author{
Fernanda Cristina Pereira de Oliveira \\ Mestre em Geografia pela Universidade Federal do Paraná (UFPR) \\ Departamento de Geografia \\ Curitiba, $P R$ \\ e-mail:fcp_geo@yahoo.com.br \\ Chisato Oka-Fiori \\ Professora da Universidade Federal do Paraná (UFPR) \\ Departamento de Geografia \\ Curitiba, $P R$ \\ e-mail:piofiori@terra.com.br \\ Mário Sérgio de Melo \\ Professor da Universidade Estadual de Ponta Grossa (UEPG) \\ Departamento de Geociências \\ Ponta Grossa, PR \\ e-mail:msmelo@br10.com.br \\ Claudia Inês Parellada \\ Pesquisadora do Museu Paranaense \\ Departamento de Arqueologia \\ Curitiba, $P R$ \\ e-mail: parelladaclau@ig.com.br
}

\section{Resumo}

O presente trabalho desenvolveu-se na região de Piraí da Serra. Essa área está localizada na região fitogeográfica dos Campos Gerais do Paraná, que devido à sua geologia e geomorfologia peculiar, proporcionou em tempos passados a ocupação 
de muitos abrigos, onde diferentes populações fizeram pinturas rupestres. Os registros das pinturas são fontes inesgotáveis de informações arqueológicas que podem e devem ser estudados sob diversos aspectos (antropológico, cronológico, de comunicação, como processos artísticos e estéticos e do imaginário humano; além de estudos paleoclimáticos e paleoambientais). As tradições rupestres constatadas são a Planalto, com predominância de representações de cervídeos e figuras humanas em movimento, figuras de prováveis pés de milho, e representações relacionadas à Tradição Geométrica. É extremamente necessário pesquisar o contexto histórico-geográfico dos abrigos com pinturas rupestres para que se possam identificar os diversos grupos culturais que habitaram a região de Piraí da Serra ao longo do tempo e em determinadas condições ambientais. Devido à sua abundancia são necessários maiores estudos e uma adequada gestão desse patrimônio arqueológico, pois parte se encontra degradado por ação natural e depredado por ações humanas. O estudo buscou aprofundar os conhecimentos ambientais e históricos para adequada gestão do patrimônio arqueológico, caracterizando e espacializando os abrigos com pinturas rupestres por meio de um SIG (Sistemas de Informação Geográfica). O tratamento dos dados levantados possibilitou a organização de um banco de dados que dinamizará a conservação da área.

Palavras-chave: Arqueologia, Arte Rupestre, Geoprocessamento, Campos Gerais.

\begin{abstract}
The present work developed in the region of Piraí da Serra. This area is located in the phytogeographic region of Campos Gerais do Paraná, due to its unique geology and geomorphology, provided in past times the occupation of many shelters, where different populations did rock paintings. The records of the paintings are inexhaustible sources of archaeological information that can and should be studied under several aspects (anthropological, chronological, of communication, such as artistic and aesthetic processes and the human imagination; and paleoclimatic and paleoenvironmental studies). The rock art traditions observed are called Planalto, with a predominance of depictions of deer and human figures in motion, like figures feet of corn, in addition of representations related to Geometric Tradition. It is extremely necessary to search the geo-historical context of shelters with rock paintings in order to identify the various cultural groups that inhabited the region of Piraí da Serra over time and under certain environmental conditions. This abundant archaeological heritage shows the need of larger studies and proper management, because part of it has been degraded by natural action and trashed by human actions. The study sought to deepen the environmental and historical knowledge for proper management of archaeological heritage, characterizing and spatializing the shelters with rock paintings through a GIS (Geographic Information Systems). The treatment of data collected enabled the organization of a database that will boost the conservation of the area.
\end{abstract}

Keywords: Archaeology, Rock Art, Geoprocessing, Campos Gerais. 


\section{INTRODUÇÃO}

Piraí da Serra é uma denominação local e encontra-se na região fitogeográfica dos Campos Gerais do Paraná, no reverso imediato da Escarpa Devoniana, sobre o eixo do Arco de Ponta Grossa, marcado por muitos diques de diabásio e rochas associadas que cortam a Formação Furnas (PEREIRA, 2009). Segundo Melo et al. (2004) essa região se destaca por apresentar um "contrastante relevo de topos aplainados com campos e rios encaixados em canyons paralelos na direção NW-SE, onde ocorre floresta de araucária."

Conforme ilustrado na Figura 01, Piraí da Serra situa-se na porção CentroNordeste dos Campos Gerais do Paraná, e está delimitada a nordeste (NE) pela rodovia PR-090, a sudeste (SE) pela Escarpa Devoniana, a sudoeste (SW) pelo Rio lapó e a noroeste (NW) pelo Rio Fortaleza- Guaricanga (Figura 01). Este limite engloba partes de três municípios: Castro a SE, Piraí do Sul a N e NE, e Tibagi a SW, com uma área total de $519 \mathrm{~km}^{2}$, sendo deste total $7 \mathrm{~km}^{2}$ são ocupados por oito morros testemunhos localizados no extremo sul da área (KÖENE, 2009).

Esta área foi investigada pela ocorrência de pinturas rupestres e por apresentar associações de fatores ambientais únicos: rios antecedentes encaixados em profundos canyons paralelos na direção NW-SE (direção do eixo do arqueamento da crosta terrestre), alguns com belíssimas cachoeiras; exposição de rocha em paredões e relevo ruiniforme; formações vegetais bem diversificadas (Floresta Ombrófila Mista, Mata Estacional Semidecídua, Cerrado e Campo Nativo) testemunhas de condições climáticas no passado e atuais; solos pobres e rasos derivados das rochosas areníticas, e solos férteis proporcionados pelos diques que condicionam uma vegetação arbórea bastante densa e feições de erosão subterrânea que se estendem à superfície do terreno (furnas, sumidouros e túneis).

A presença do obstáculo natural representado pela Escarpa Devoniana, onde os vales encaixados dos rios que correm para oeste constituem passagens naturais, e a ocorrência de rochas susceptíveis ao desenvolvimento de cavidades naturais, com dimensões variadas, que posteriormente foram ocupadas por populações précoloniais, sendo que parte desses abrigos possui pinturas rupestres relacionadas a 
diversos grupos culturais, contribuíram para que esta região fosse alvo de diversas pesquisas.

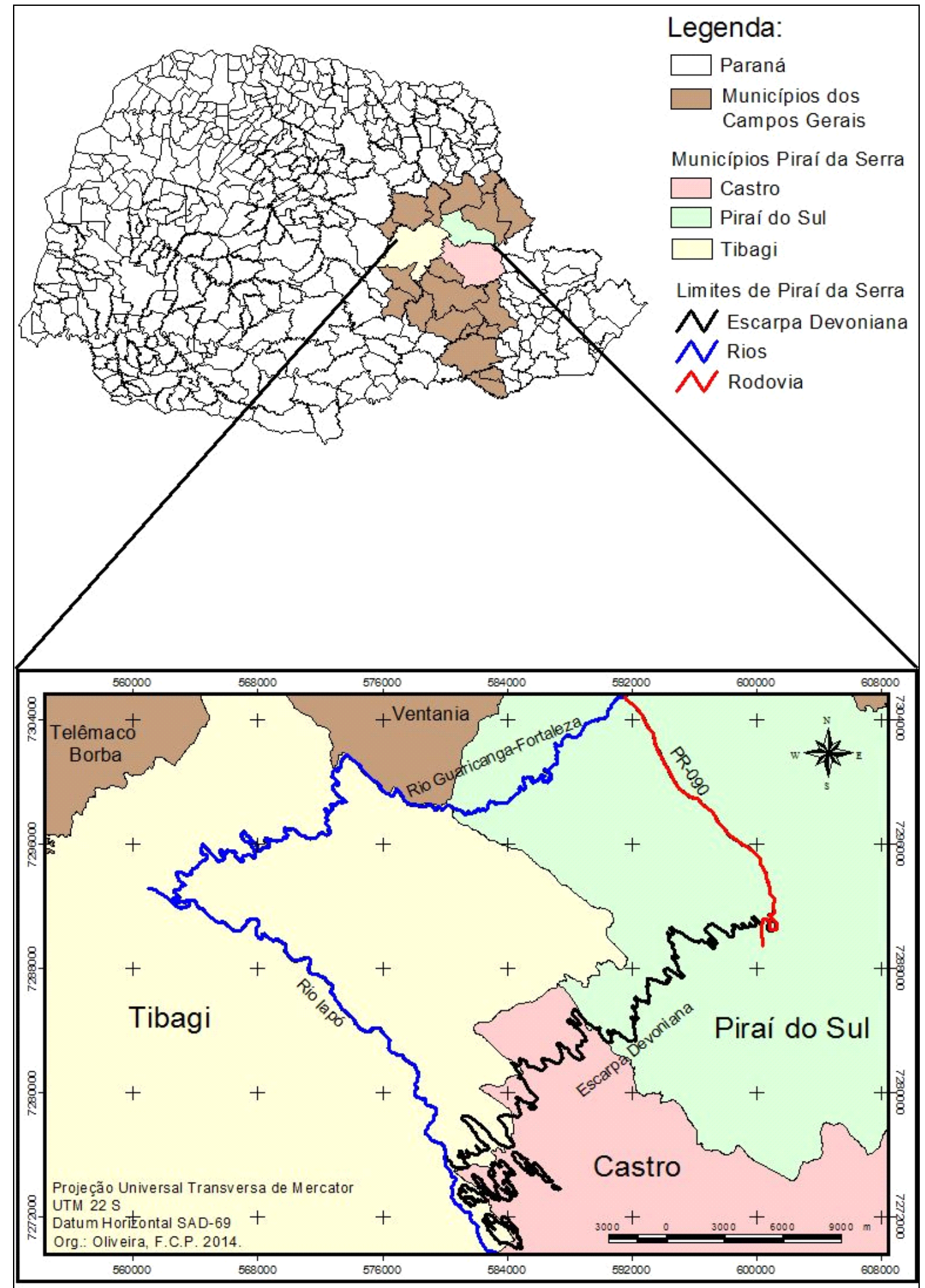

Figura 01: Mapa de localização da região de Piraí da Serra - Paraná. Fonte: UEPG, 2003; Pereira, 2009. 
Nos locais onde foram caracterizadoras as pinturas rupestres há a ocorrência da ação de diversas intempéries, como vento, umidade, ação da luz, dilatação e retração da rocha que acabaram recobrindo as pinturas, danificando-as e diminuindo sua visibilidade; um dos principais agravantes e o que mais preocupa os arqueólogos atualmente é a ação do próprio homem. Além das intempéries, o avanço da agricultura e da pecuária na região vem favorecendo a degradação dos sítios arqueológicos, uma vez que o gado passa muito próximo aos sítios, pisoteando as áreas que podem conter vestígios líticos; as queimadas utilizadas para a preparação da terra para o plantio soltam fuligem que acabam fixando-se nas pinturas danificando-as, deixando-às escuras (pretas), os reflorestamentos de exóticas e grandes empreendimentos, inclusive do setor elétrico, podem danificar sítios arqueológicos ou até mesmo deixá-los submersos; e por último a ação de turistas (campistas) que ao se abrigarem nos sítios fazem fogueiras que também acabam danificando as pinturas, além de marcá-las com a utilização de picaretas e canivetes.

Os estudos propostos visam sistematizar os dados disponíveis, no sentido de diminuir a lacuna de conhecimentos sobre dados arqueológicos da região de Piraí da Serra, pois se verificou a existência de muitos abrigos com pinturas rupestres, porém com poucas informações contextualizadas e datadas, que poderiam permitir uma análise mais detalhada das pinturas rupestres já encontradas nos abrigos da região de Piraí da Serra.

\section{MATERIAIS E PROCEDIMENTOS METODOLÓGICOS}

Os procedimentos metodológicos utilizados na pesquisa compreenderam as seguintes etapas principais:

- Atualização dos dados existentes levantados pelo Projeto "Diagnóstico ambiental da região de Piraí da Serra - PR, visando à sustentabilidade regional", entre os anos de 2007 a 2009. Esse banco de dados foi realizado por diversos pesquisadores e bolsistas de iniciação científica da UEPG. Nele constam informações relativas aos pontos coletados em campo: características geológicas, 
geomorfológicas, pedológicas, hidrográficas, biológicas, arqueológicas, antropológicas, históricas e fotográficas, e entre outras;

- Levantamento bibliográfico em monografias, teses e relatórios dos bolsistas de iniciação científica da Universidade Estadual de Ponta Grossa (UEPG), entre os anos de 2007 e 2009 sobre as características fisiográficas da área, sobre sítios arqueológicos, pinturas rupestres e patrimônio arqueológico; livros e artigos sobre SIG, arqueologia e APA da Escarpa Devoniana;

- Fotointerpretação em fotografias aéreas pancromáticas em escala 1: 70.000 dos anos de 1962/1963 (DGTC - Departamento de Geografia, Terras e Colonização do Estado do Paraná). As quais foram fotointerpretadas com estereoscópio binocular com espelho de mesa e extraída, em overlays, muitas informações relevantes sobre a geologia, geomorfologia, hidrografia, vegetação e arqueologia regional. Posteriormente essas informações foram digitalizadas no software ArcView 3.2, utilizando como base as ortoimagens do Sensor SPOT 5;

- Levantamentos de campo para aquisição de dados sobre os sítios arqueológicos e das pinturas rupestres encontradas e de possíveis novos sítios. Além da coleta de diversas informações da área, contendo as características físicas e humanas da região que puderam compor o banco de dados de Piraí da Serra. Nesse levantamento constam registros fotográficos, anotações diversas em caderneta e algumas fichas de pontos particulares, como dos sítios arqueológicos com pinturas rupestres.

- Levantamentos de campo para aquisição de novos dados fotográficos. Foram registrados todos os pontos visitados na área de Piraí da Serra pelos integrantes do projeto, entre os anos de 2007 e 2009. Esses registros constam num banco de dados do projeto Piraí da Serra (UEPG) e da própria autora;

- Elaboração de fichas para coleta de dados arqueológicos e fisiográficos de cada abrigo que complementarão o banco de dados dos sítios encontrados na área.

- Utilização da Ortoimagem do Sensor SPOT 5 com resolução espacial de $5 \mathrm{~m}$ cedidas pelo PARANACIDADE/SEDU (Secretaria do Estado de Desenvolvimento Urbano) do ano de 2005. Sendo ela um mosaico das imagens: MI 2807-3; MI 2807-4; MI 2824-1; MI 2824-2. Essa imagem foi utilizada como base para a 
digitalização de alguns temas (hidrografia e drenagem) e como forma de localização de determinadas feições de relevo e outras informações pertinentes a pesquisa.

As informações coletadas em campo (anotações em caderneta e pontos coletados com o receptor GPS Etrex Garmim Vista) e nas fotografias aéreas foram cruzadas com os dados coletados nas ortoimagens, os quais geraram como produto final mapas com temáticas diversificadas, utilizados pelos pesquisadores do projeto nos artigos, trabalhos publicados em anais e apresentações dos mesmos, nas monografias e dissertações dos alunos envolvidos na pesquisa, tais como a dissertação da autora.

- Geração de mapas temáticos em ambiente SIG utilizando o software Arcview 3.2, com as características fisiográficas da região (geologia, geomorfologia, vegetação e hidrografia) para análise arqueológica dos abrigos com pinturas rupestres existentes em Piraí da Serra.

- Geração e atualização de um banco de dados em ambiente SIG com informações dos abrigos, contendo um ID (identificação do ponto), nome dos abrigos, tradição arqueológica, coordenadas, altitude de cada abrigo relacionado e as características físicas dos mesmos (material de piso) - se é possível escavação ou não.

Com o intuito de dinamizar a conservação da área estudada, foi realizado um tratamento dos dados levantados por meio da organização de um banco de dados em um SIG, onde os abrigos com pinturas rupestres foram espacializados.

Sendo assim, o SIG permite a representação do mundo real interrelacionando dados espaciais, funcionando, portanto, como uma base de dados com informação geográfica (dados alfanuméricos) que se encontra associada por um identificador comum aos objetos gráficos de um mapa digital. Desta forma, assinalando um objeto pode-se saber o valor dos seus atributos, e inversamente, selecionando um registro da base de dados é possível saber a sua localização e apontá-la num mapa, pois são dados georreferenciados. Portanto, ao se alterar os valores no banco de dados, concomitantemente os abrigos serão modificados na 
localização espacial, isto se deve ao fato de se tratar de um SIG, onde os dados espaciais e não espaciais estão interligados.

\section{RESULTADOS E DISCUSSÃO}

A geologia da região é representada por Unidades da Bacia Sedimentar do Paraná que, sengundo Retzlaf et al. (2006, p.97), é uma bacia intracratônica e "possui mais de 5.000 metros de rochas sedimentares e vulcânicas, e seu embasamento é composto por rochas magmáticas e metamórficas".

Conforme mostrado na Figura 02, a geologia da região de Piraí da Serra é composta por rochas da Formação Furnas, Formação Ponta Grossa e raros locais de afloramento da Formação lapó, e intercalações de corpos ígneos intrusivos mesozóicos relacionados ao Magmatismo Serra Geral.

A Formação Furnas é a unidade geológica com maior representatividade em Piraí da Serra, cerca de 86\% da área (Köene, 2009), com exposições de rocha em quase todo o seu domínio, especialmente no trecho mais próximo à Escarpa Devoniana, rareando a partir da metade da área em direção ao Rio FortalezaGuaricanga (NE).

$\mathrm{Na}$ área foram encontrados trinta abrigos com pinturas rupestres (Figura 03), que estão associados a afloramentos do Arenito Furnas e nas proximidades de falhas, fraturas e diques de diabásio.

No município de Piraí do Sul encontram-se vinte e quatro abrigos: Cachoeira; Cachoeira Canyon Arroio Palmeirinha; Chapadinha I e II; Cuiacá I e II; Fazenda das Cavernas 1 e 2; Guaricanga I e II; Paulino I, II e II; Santa Rita I e II; São José da Lagoa I e II; Serra do Piraí 1 e 2; Silvano; Tarumã; Vitão; PS-415 e PS-421. Esses dois últimos sítios foram encontrados pela pesquisadora Cinara de Souza Gomes em 2013, e até o momento não receberam nomes definitivos. No município de Tibagi encontram-se os abrigos: Cachoeira Bico do Pato 1, 2 e 3; Casa de Pedra A e B; e Ponte Alta. 


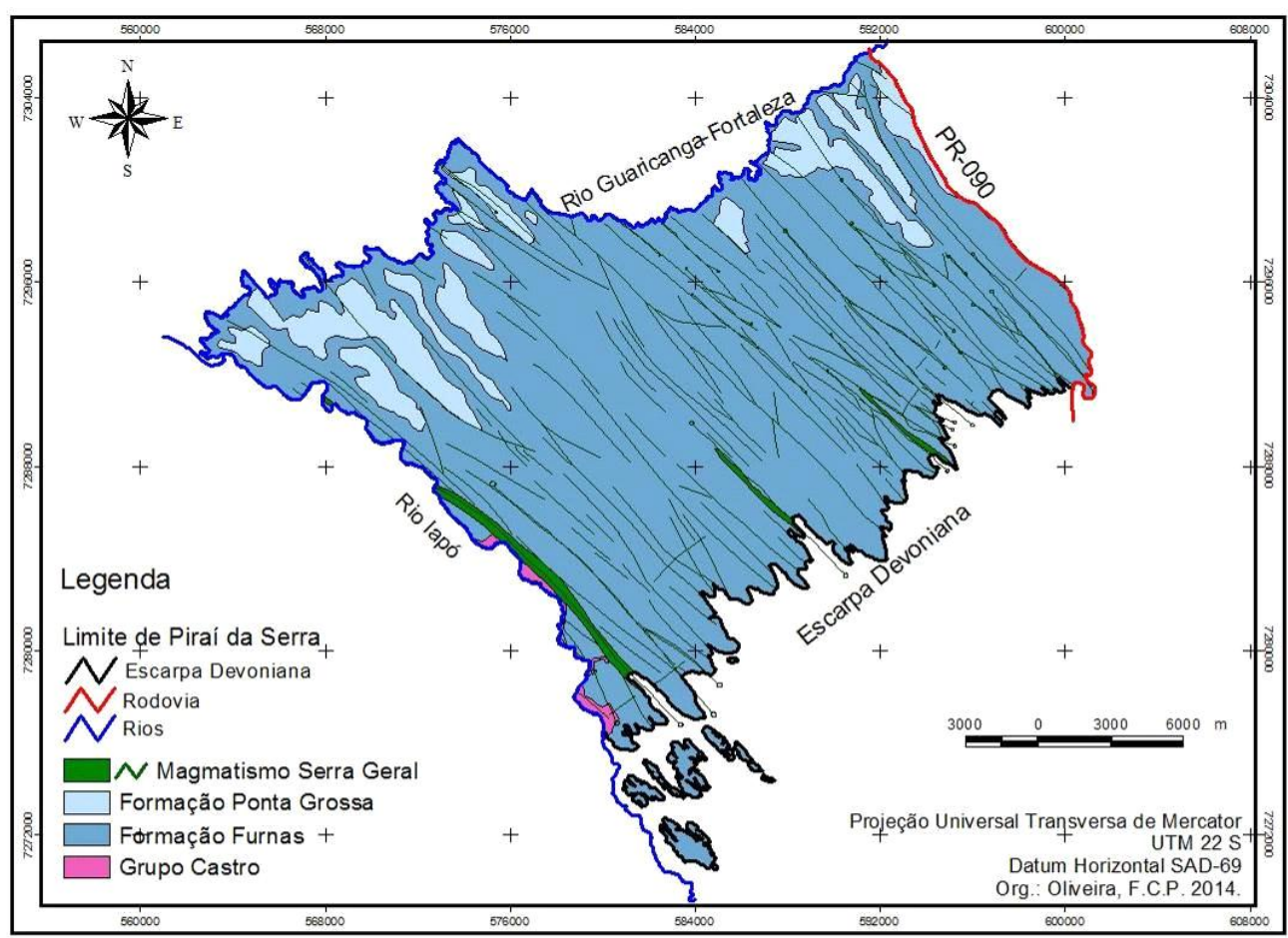

Figura 02: Mapa de geologia da região de Piraí da Serra - Paraná.

Fonte: UEPG, 2003; Mineropar, 2006; Pereira, 2009; Köene, 2009; Mochiutti, 2009.

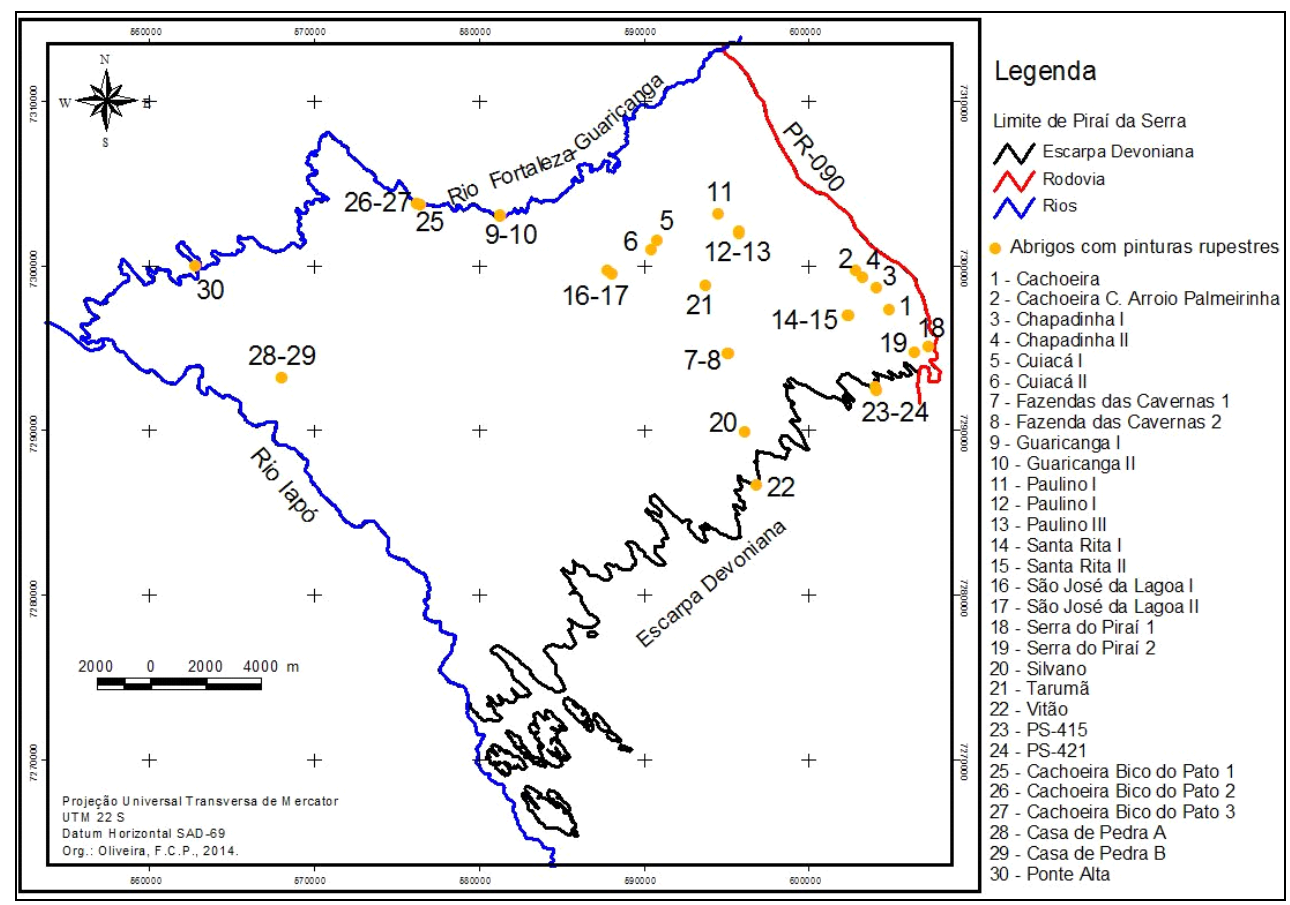

Figura 03: Mapa com localização dos abrigos com pinturas rupestres em Piraí da Serra - Paraná. Fonte: Pereira, 2009.

Os sítios arqueológicos são os locais onde existem vestígios (a maior parte preservado) de populações humanas, a maioria entre dez mil anos atrás até o 
século XX. Segundo Prous et al. (2003) quando se encontram isolados de um contexto cronológico, cultural e funcional, os vestígios arqueológicos fornecem pouquíssimas informações para a Arqueologia, pois um arqueólogo não estuda o objeto isolado, mas sim o conjunto arqueológico por inteiro (estrutura arqueológica).

Os vestígios arqueológicos são as testemunhas da presença e das atividades do homem, e estão relacionados com o meio ambiente no qual vivia. As pinturas rupestres são o resultado de uma ação voluntária, são marcas conscientes da presença humana dos diferentes povos que ocupavam um determinado território. As pinturas compõem pontos de referência na paisagem e passam uma mensagem de difícil interpretação para observadores de outro tempo e pertencentes a outros contextos culturais, mas podem ser identificados possíveis temas preferenciais e estilos diferenciados.

Os sítios arqueológicos com características semelhantes e pertencentes a um mesmo período foram classificados em tradições para serem mais facilmente compreendidos. O conceito de tradição rupestre compreende a caracterização de uma linguagem visual de um determinado universo simbólico que provavelmente está relacionado a grupos culturais afins. Para Prous (1992) o termo tradição é o conjunto mais abrangente entre as unidades rupestres descritivas, implicando certa permanência de traços temáticos. Segundo Parellada (2008, p.125) "a tradição, de uma forma geral, ainda se caracteriza na estratégia classificatória de dados arqueológicos mais usados no Brasil, e vem permitindo e permeando a maior parte dos diálogos de arqueologia regional."

As tradições paranaenses que se relacionam com as pinturas rupestres são as tradições Planalto e Geométrica (Parellada, 2007, 2009; Silva, Parellada e Melo, 2007; Silva, Melo e Parellada 2007), sendo, portanto as mesmas tradições rupestres representadas nos abrigos em Piraí da Serra (Pereira; Melo e Parellada, 2008). Esses grupos de pinturas rupestres datam do período pré-colonial, e algumas podem alcançar até 10.000 anos atrás.

A Tradição Planalto, segundo Prous (1992) e Parellada (2013), apresenta grafismos pintados geralmente em vermelho, e mais raramente em preto ou amarelo, algumas vezes em branco, predominando as figuras de animais, como 


\section{AS PINTURAS RUPESTRES NA REGIÃO DE PIRAÍ DA SERRA, PARANÁ.}

cervídeos em perfil e pássaros tanto em perfil como de frente. Menos comumente podem ocorrer figuras humanas e motivos geométricos associados, alguns considerados como astronômicos, por se assemelharem a cometas ou a sóis.

No vales dos rios lapó e Tibagi as pinturas rupestres ocorrem principalmente em marrom e vermelho, e mais raramente em preto, e a maioria é claramente correlacionável a Tradição Planalto, devido à predominância de figuras de animais, tais como cervídeos, pássaros, répteis e outros. Sendo as representações de cervídeos as mais comuns nos abrigos da região, dependendo do abrigo os possíveis animais apresentam o corpo contornado, chapado ou totalmente preenchido (Figuras 04 a 09) (Pereira, 2009).

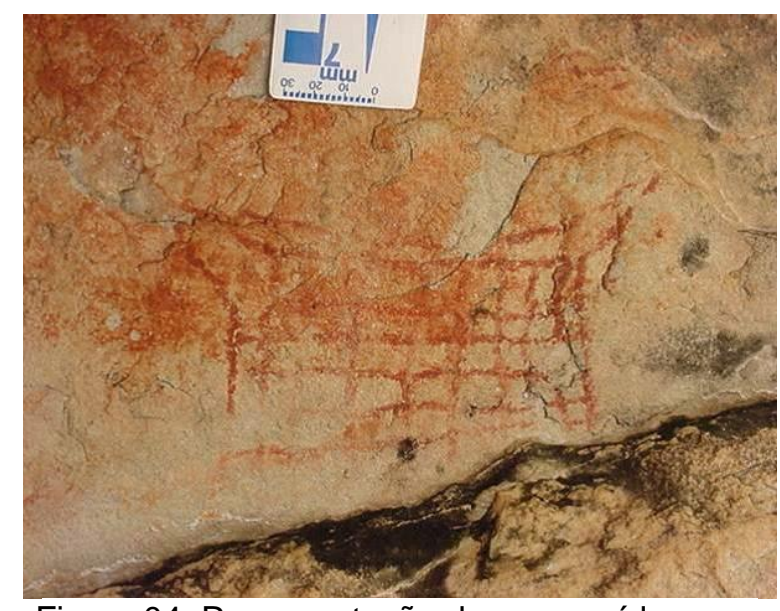

Figura 04: Representação de um cervídeo no Abrigo Chapadinha I, Piraí do Sul, Paraná. Fonte: Pereira, 2009.

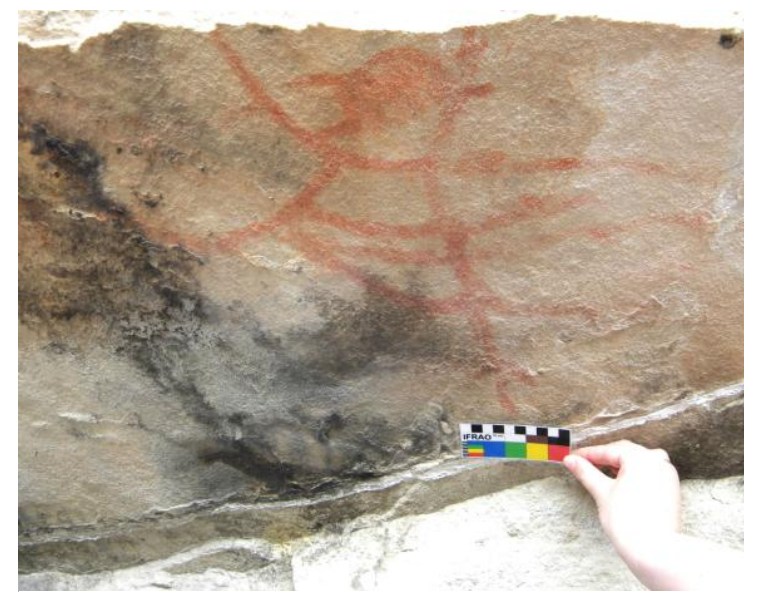

Figura 05: Representação de um ser fantástico - Abrigo Chapadinha I, Piraí do Sul, Paraná.

Fonte: Acervo pessoal de Claudia Inês Parellada, 2011. 


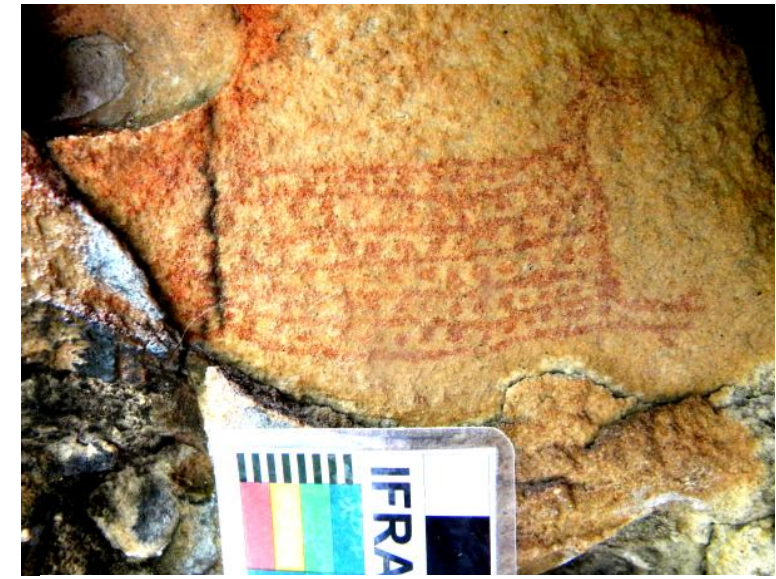

Figura 06: Cervídeo pequeno em alvéolo na parede do abrigo Chapadinha II - Piraí do Sul, Paraná.

Fonte: Acervo pessoal de Claudia Inês Parellada, 2011.

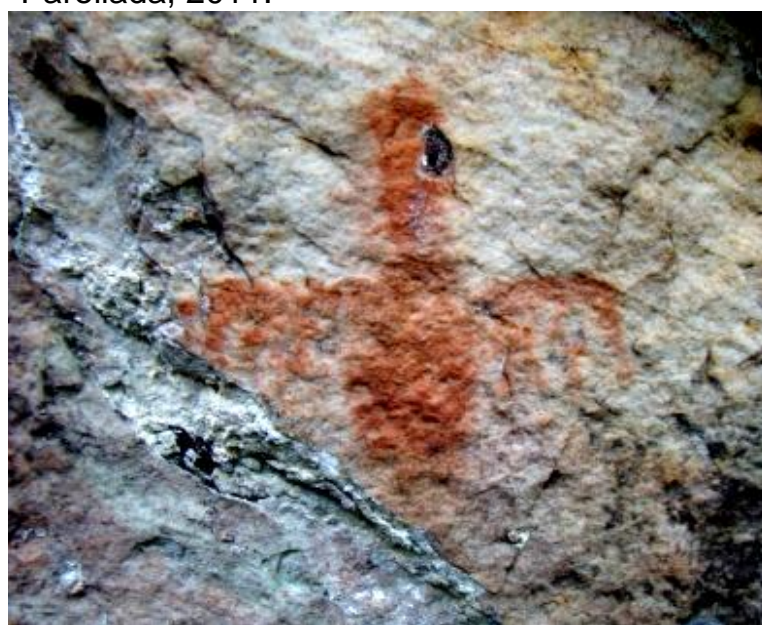

Figura 08: Representação de uma provável ave no Abrigo Cavernas II.

Fonte: Pereira, 2009.

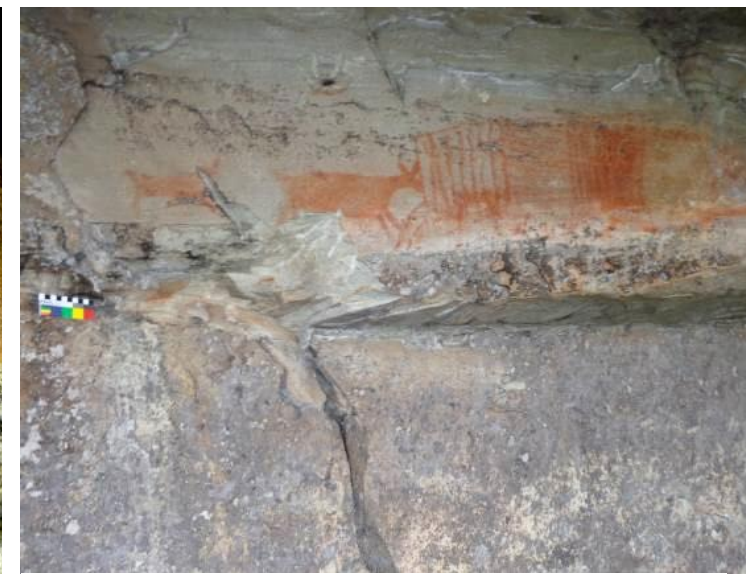

Figura 07: Painel representando uma cena no Abrigo Cavernas I - Piraí do Sul, Paraná. Fonte: Acervo de Fernanda C. Pereira de Oliveira, 2014.

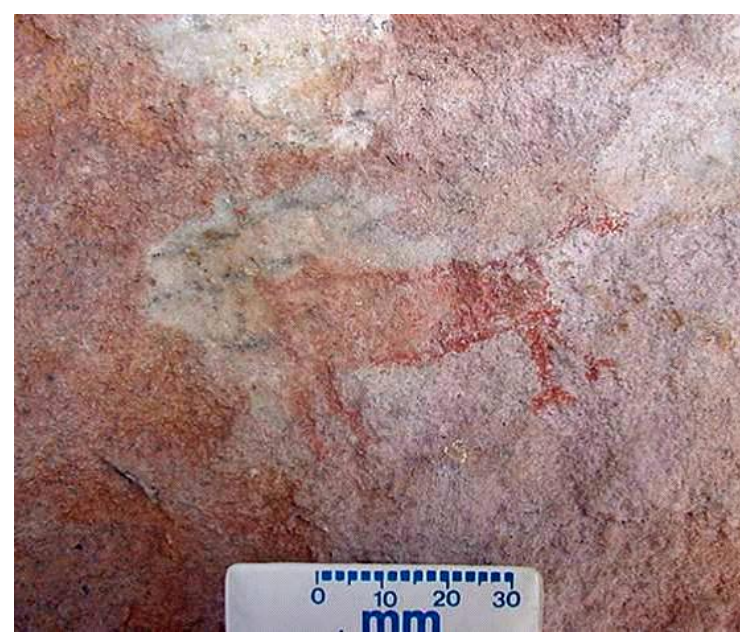

Figura 09: Representação de um cervídeo na parede do Abrigo Paulino III.

Fonte: Pereira, 2009.

Ocorre ainda no abrigo São José da Lagoa II representações raras no estado do Paraná, são representações de figuras humanas que também podem ser encontradas no abrigo Usina São Jorge em Ponta Grossa pesquisado por Silva; Parellada e Melo (2007). No abrigo São José da Lagoa II aparecem aproximadamente 200 pinturas rupestres, sendo a grande maioria delas de seres humanos em movimento que configuram um complexo painel (Figura 10). A estimativa é que essas pinturas tenham sido realizadas há aproximadamente 4 mil anos por populações Jê, esse painel possivelmente retrata uma cena mítica expressando danças rituais (PARELLADA, 2014). 


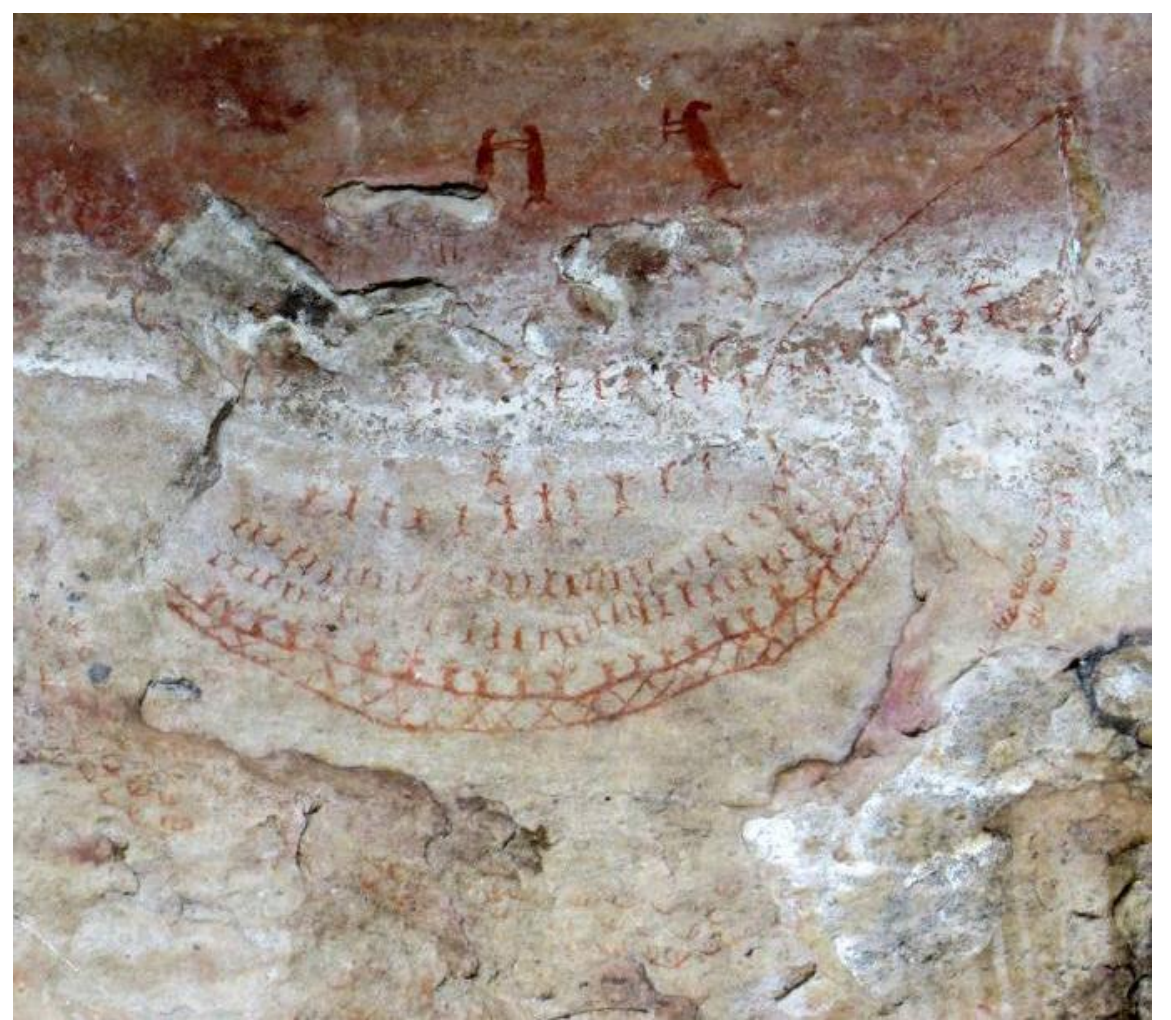

Figura 10: Painel com pinturas rupestres - Abrigo São José da Lagoa II, Piraí do Sul, Paraná. Fonte: Acervo pessoal de Claudia Inês Parellada, 2014.

De acordo com Oliveira (2014) essas pinturas de humanos estão envolvidas por três semicírculos grandes: o primeiro é representado por cabeças de cervídeos unidas "por uma faixa com linhas internas, em X, contínuas e dois mais afastados do centro do conjunto, e próximos entre si, com representações de pequenos semicírculos com duas linhas internas" (Parellada; Oliveira e Sclvilzk, 2014) (Figuras 10 a 12). No alto do painel estão três representações de seres fantásticos que se assemelham a animais com características humanas, eles são bem maiores do que as demais pinturas que compõe o painel (Parellada; Oliveira e Sclvilzk, 2014) (Figuras 13). Ainda aparecem outras representações não identificadas (Figura 14). 


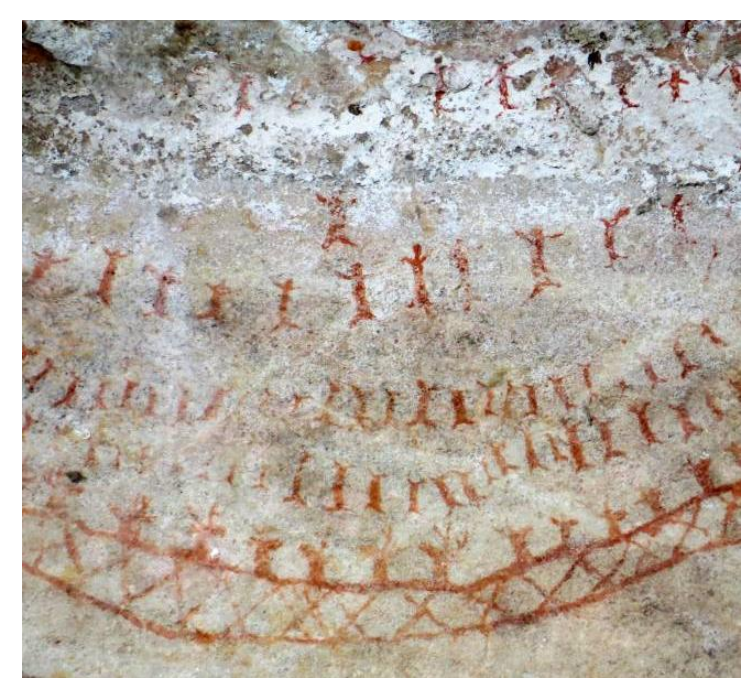

Figura 11: Pinturas rupestres de humanos, cabeça de cervídeos e linhas - Abrigo São José da Lagoa II, Piraí do Sul, Paraná.

Fonte: Acervo pessoal de Claudia Inês

Parellada, 2014

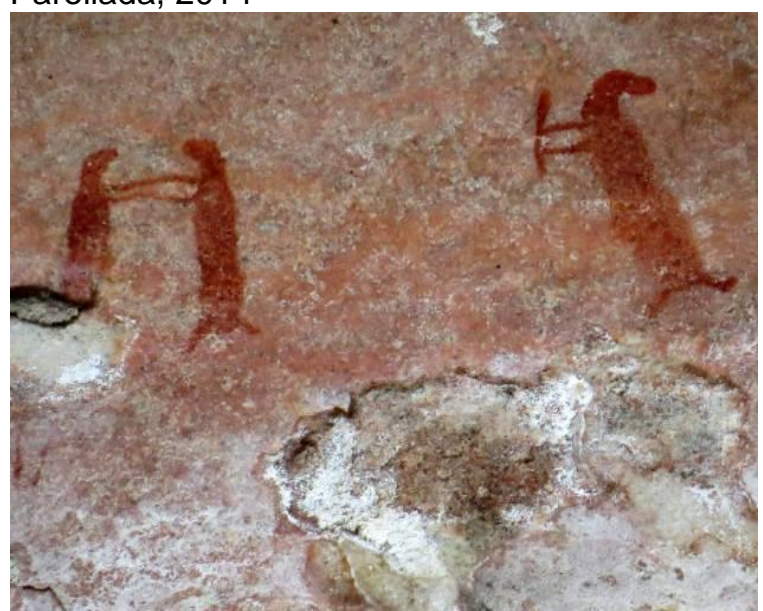

Figura 13: Pinturas rupestres de seres fantásticos - Abrigo São José da Lagoa II, Piraí do Sul, Paraná.

Fonte: Acervo pessoal de Claudia Inês Parellada, 2014.

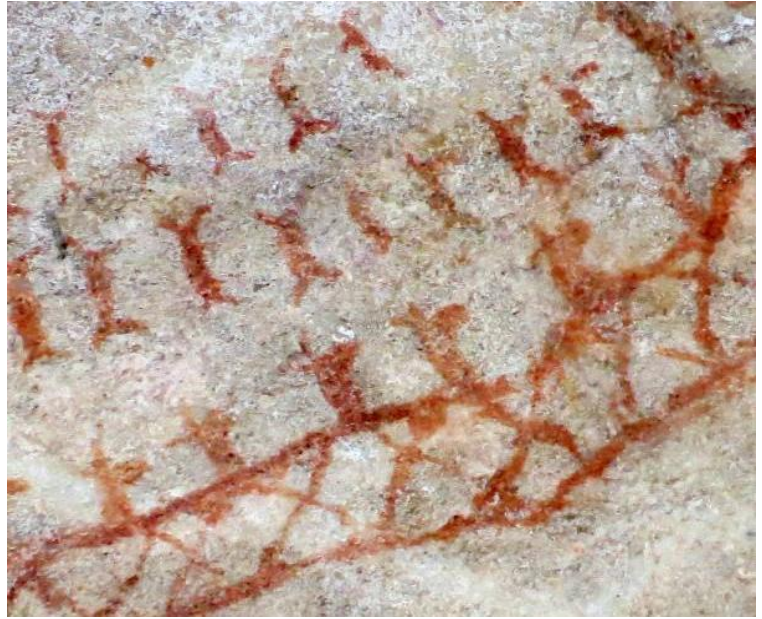

Figura 12: Pinturas rupestres de humanos, cabeça de cervídeos e linhas - Abrigo São José da Lagoa II, Piraí do Sul, Paraná. Fonte: Acervo pessoal de Claudia Inês Parellada, 2014.

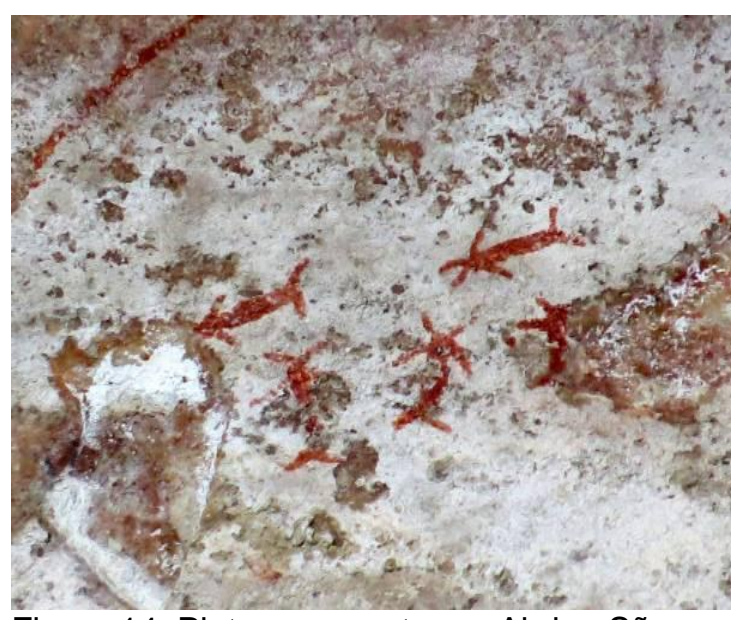

Figura 14: Pinturas rupestres - Abrigo São José da Lagoa II, Piraí do Sul, Paraná. Fonte: Acervo pessoal de Claudia Inês Parellada, 2014.

Outras representações rupestres, que são até o momento inéditas no território paranaense, ocorrem no abrigo Cachoeira Bico do Pato 1, nele aparecem duas representações de prováveis pés de milho (Figuras 15 e 16), o que se leva a pensar que o grupo que realizou tal pintura de alguma forma já praticavam a agricultura na região (Oliveira, 2014). Essas figuras fitomorfas (vegetais), segundo Jorge; Prous; Ribeiro (2007, p. 134) "são infreqüentes ou difíceis de serem reconhecidas. [...]. Nos 
estados de Minas Gerais e de Goiás, as representações vegetais parecem ligadas a plantas cultivadas anuais, como o milho".

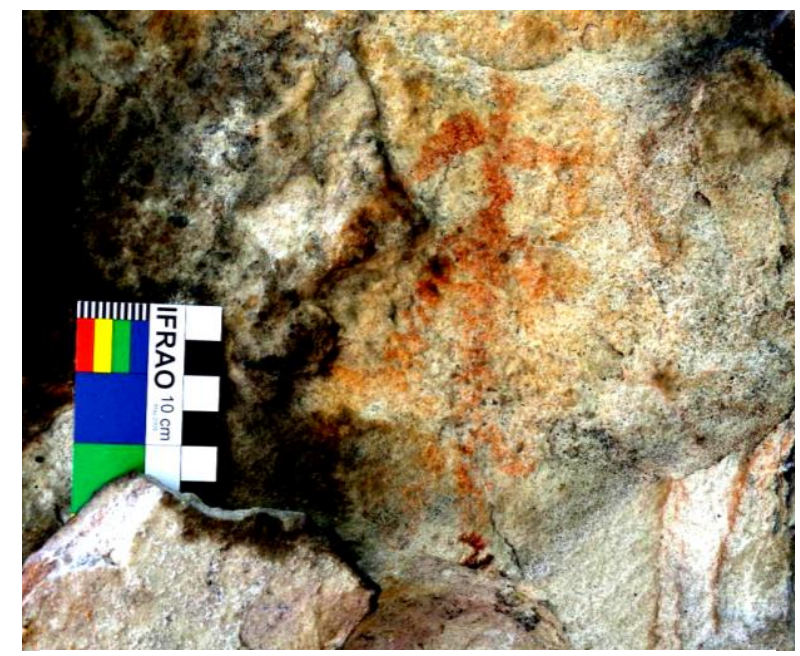

Figura 15: Painel 2: provável pé de milho Abrigo Cachoeira Bico do Pato 1, Tibagi, Paraná.

Fonte: Oliveira, 2014.

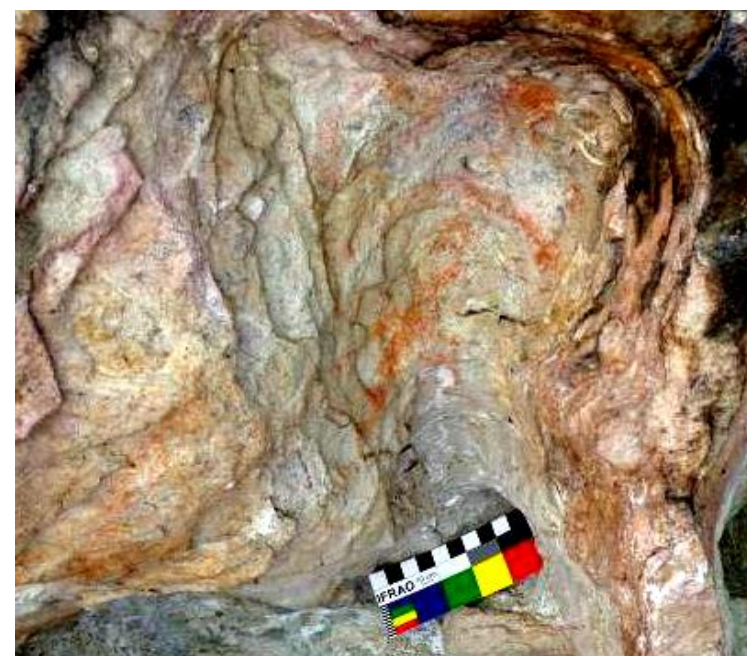

Figura 16: Painel 3: provável pé de milho e mancha de pigmento - Abrigo Cachoeira Bico do Pato 1, Tibagi, Paraná.

Fonte: Oliveira, 2014.

Associadas ou não as figuras de cervídeos podem estar pinturas relacionadas à Tradição Geométrica que se caracteriza por apresentar cor marrom e/ou vermelha e motivos geométricos (traços, círculos, linhas, pontilhados, grades e ovóides), quase não ocorrendo outros tipos de representações (Figuras 17 a 22).

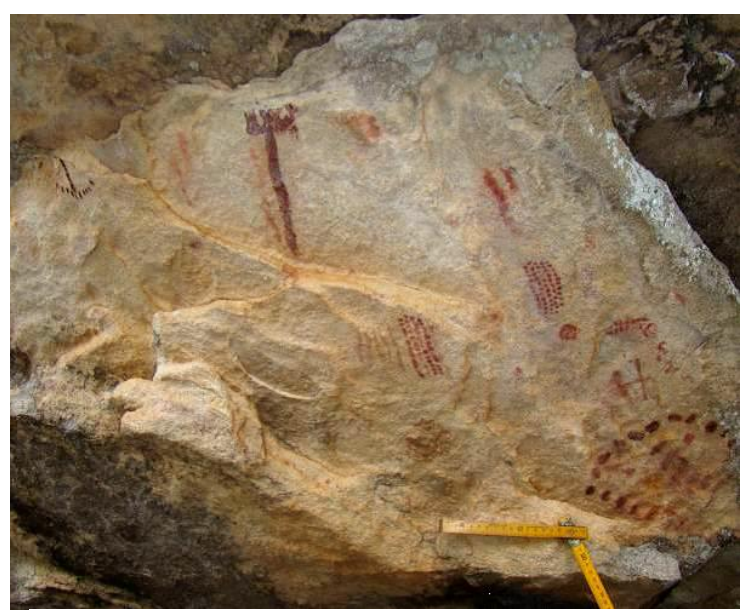

Figura 17: Painel com pinturas geométricas no teto do Abrigo Santa Rita I.

Fonte: Pereira, 2009.

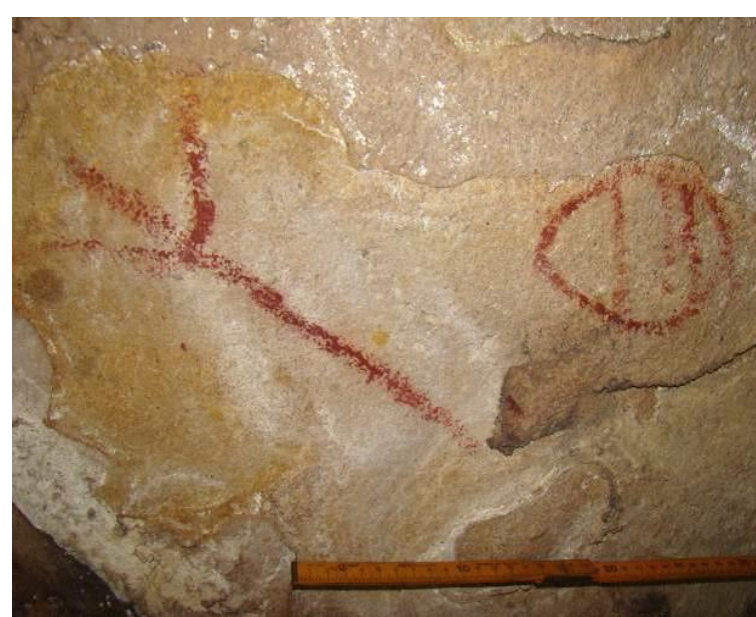

Figura 18: Ovóide e pintura semelhante a um tridente no teto do Abrigo Santa Rita I. Fonte: Pereira, 2009. 


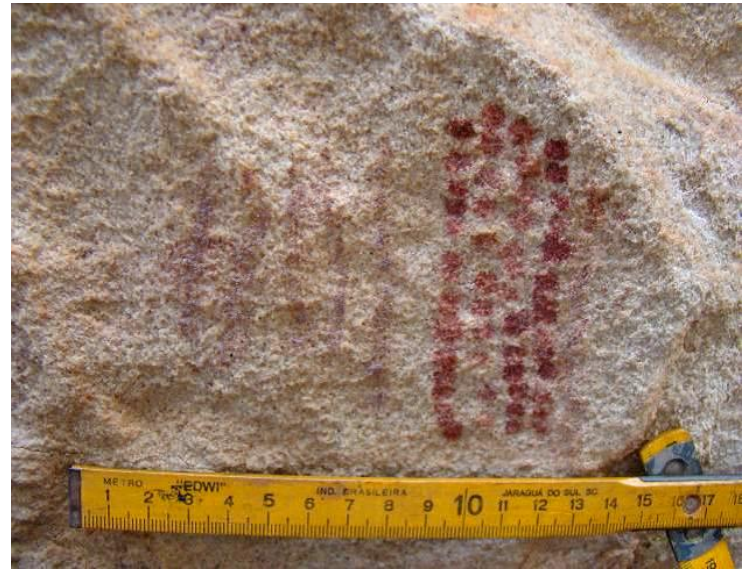

Figura 19: Representação em pontilhados e linhas na parede do Abrigo Santa Rita I.

Fonte: Pereira, 2009.

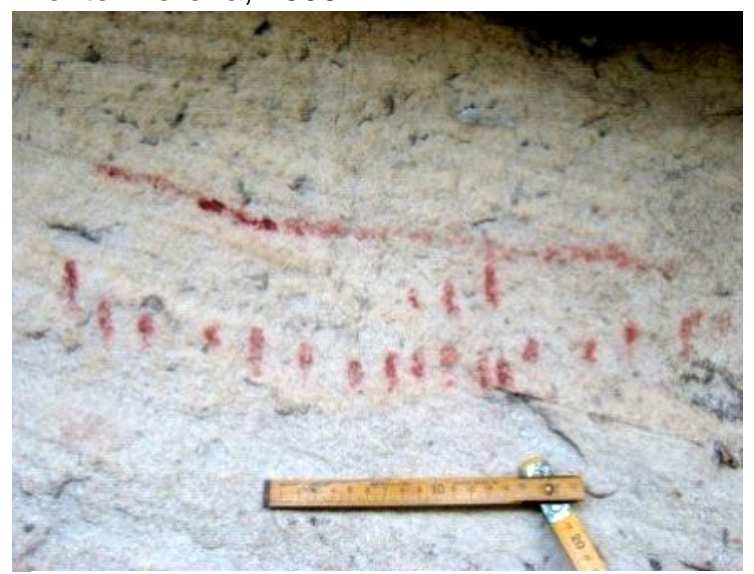

Figura 21: Pintura rupestre de uma linha reta e outra em pontos no Abrigo Santa Rita II.

Fonte: Pereira, 2009.

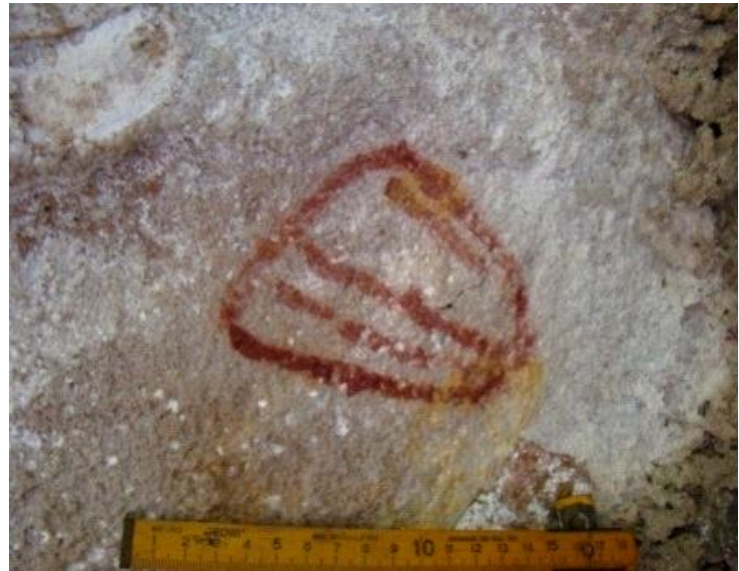

Figura 20: Pintura rupestre geométrica na parede do Abrigo Santa Rita II.

Fonte: Pereira, 2009.

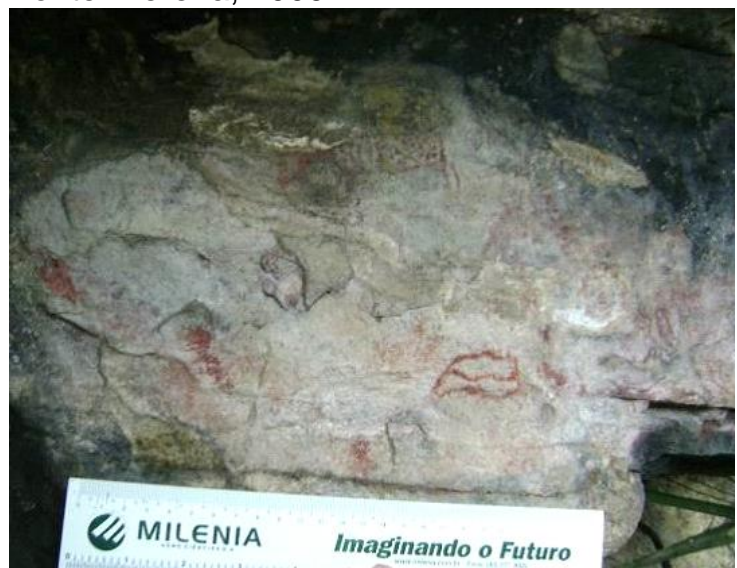

Figura 22: Representações geométricas na parede do Abrigo da Ponte Alta.

Fonte: Pereira, 2009.

A localização e o posicionamento destes abrigos podem indicar vários fatores condicionantes dos grupos indígenas pré-históricos, como: corredores de rotas migratórias, deslocamentos impostos por condições climáticas, melhor lugar para observação e captura da caça, local para rituais, etc (UEPG, 2003).

Segundo Linke (2008, p. 18) acredita-se que a relação entre as pinturas rupestres e a paisagem "se faz primeiramente no sentido da percepção, eleição, organização do espaço nos quais se realizaram atividades gráficas, ou que foram responsáveis pela produção dos grafismos". Desta forma, não se pode afirmar uma relação de subsistência entre a compreensão e interpretação das pinturas rupestres e das relações estabelecidas entres elas e a paisagem do entorno. 
Alguns abrigos são encontrados nos vales dos rios (Figura 23 e 24), outros em acentuados declives (Figura 25 e 26), e outros no topo da vertente (Figuras 27 e 28). São lugares com boa visibilidade, alguns são bem ensolarados e secos. A grande maioria dos abrigos tem sua parte frontal direcionada para o Norte, para beneficiar-se da insolação máxima o que favorece condições de salubridade (temperatura, umidade). Os poucos situados na face Sul apresentam muitas plantas e umidade no seu interior, o que influência na degradação das pinturas (UEPG, 2003).

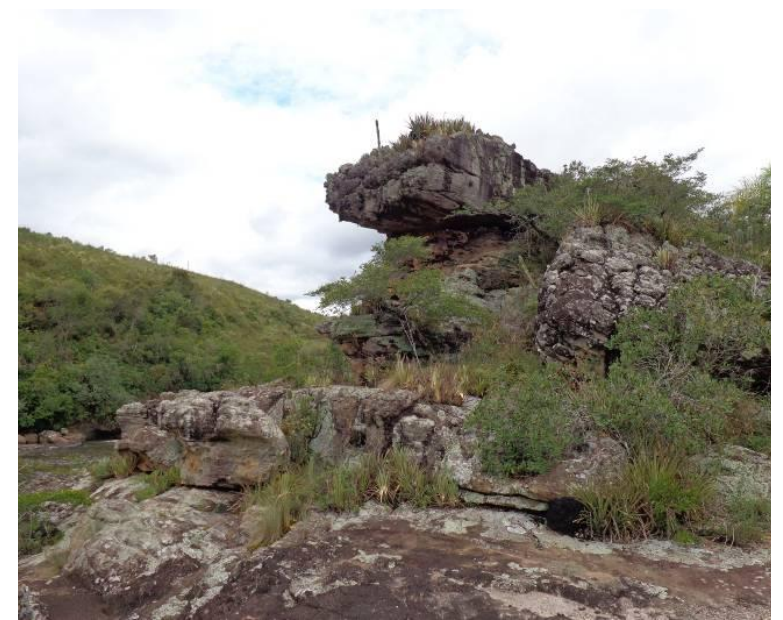

Figura 23: Entorno do abrigo Cachoeira Bico do Pato 2 - Tibagi, Paraná.

Fonte: Oliveira, 2014.

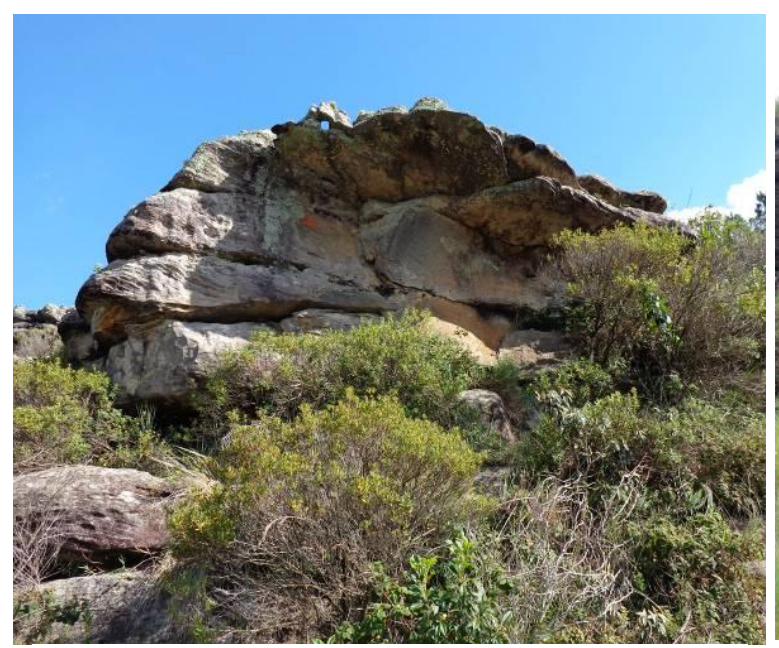

Figura 25: Abrigo Serra do Piraí 2 - Piraí do Sul, Paraná.

Fonte: Oliveira, 2014.

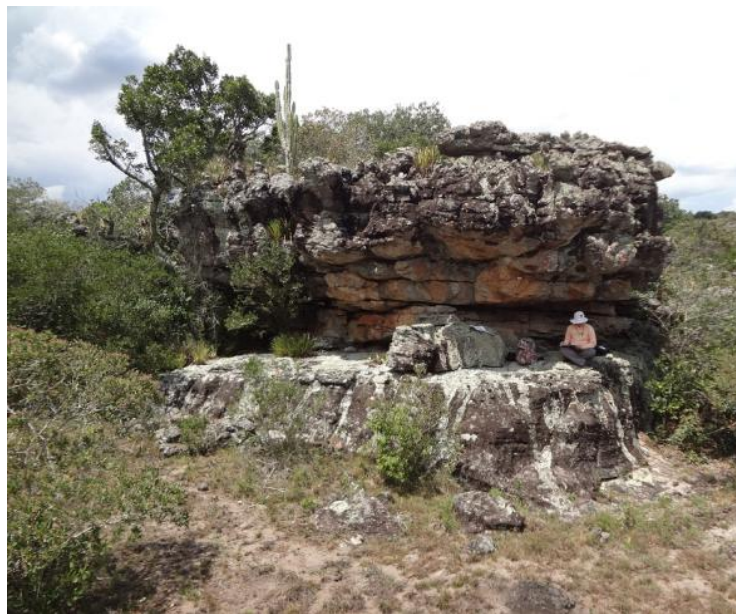

Figura 24: Abrigo Guaricanga I e paisagem do entorno - Piraí do Sul, Paraná.

Fonte: Acervo pessoal de Claudia Inês Parellada, 2014.

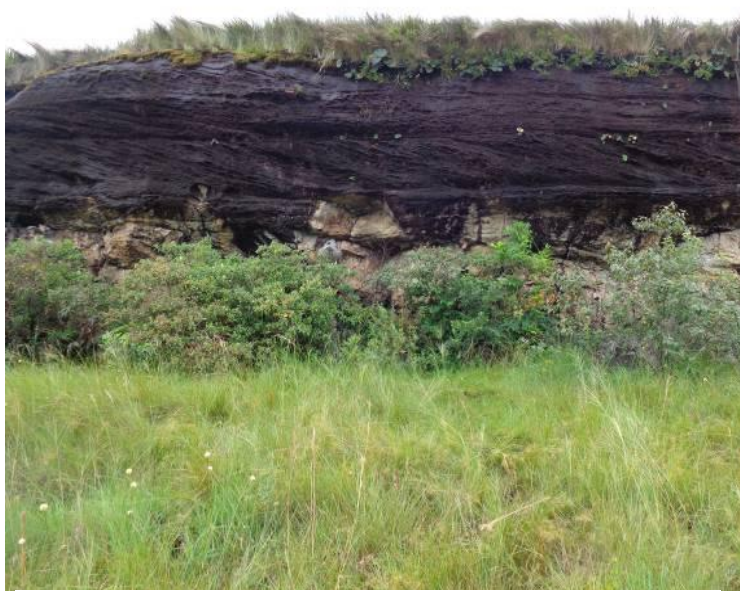

Figura 26: Abrigo São José da Lagoa I - Piraí do Sul, Paraná.

Fonte: Oliveira, 2014. 


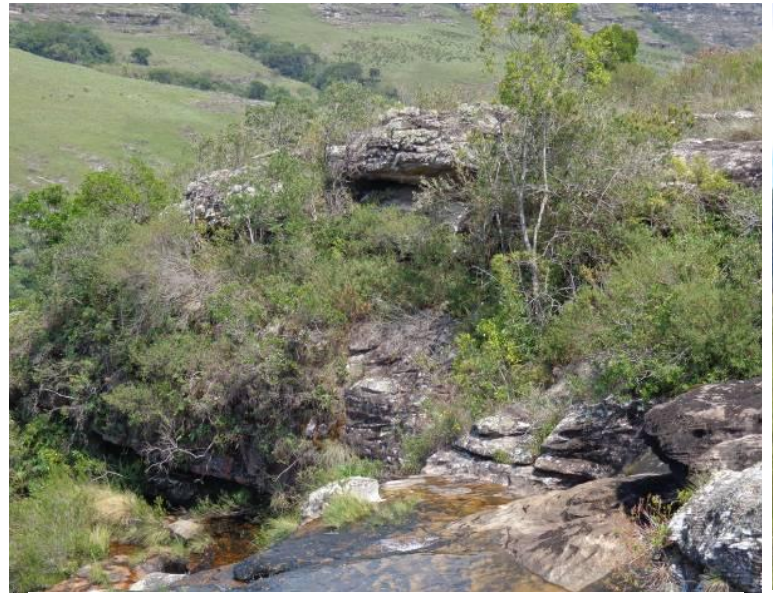

Figura 27: Abrigo Cachoeira Canyon do Arroio Palmeirinha e entorno - Piraí do Sul, Paraná. Fonte: Oliveira, 2014.

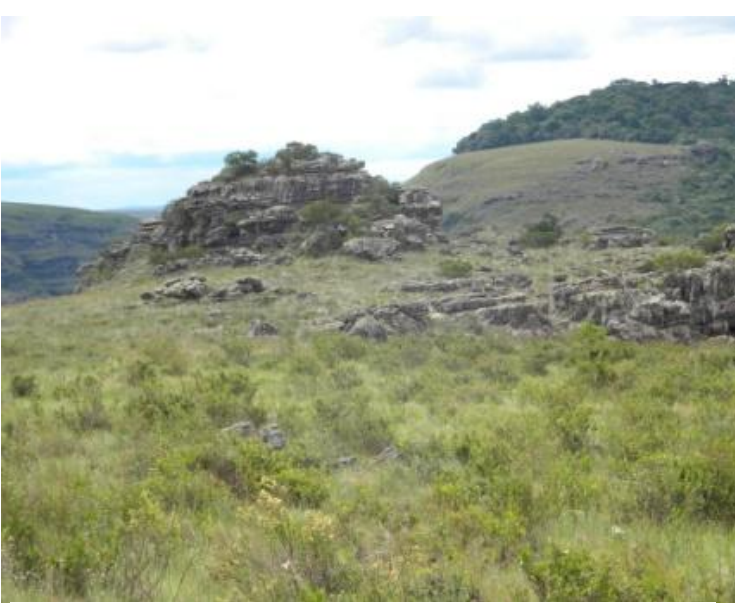

Figura 28: Abrigo Chapadinha II e seu entorno - Piraí do Sul, Paraná.

Fonte: Acervo pessoal de Claudia Inês Parellada, 2011

A relação dos registros rupestres com os recursos ambientais não pode ser atribuída apenas a questões de subsistência e de economia material, pois algumas pinturas estão relacionadas à rituais, e outras, se relacionam as cenas do cotidiano (a caça e observações astronômicas) e figuras de contagem (LINKE, 2008). No entanto, percebe-se na região certo padrão de escolha para a localização dos abrigos nas proximidades das redes de drenagem (PEREIRA, 2009; 2011), que podem ser verificados no mapa hidrográfico da Figura 29.

Os dados sobre os abrigos com pinturas rupestres foram organizados por meio de um SIG que permitem a representação do mundo real inter-relacionando dados espaciais.

De acordo com Barroso e Sousa (2007, p.83):

em um SIG a apresentação de dados tem papel relevante na extração de informações. Ela é usada para visualizar o problema, possibilitando observar, manipular e estudar os relacionamentos geográficos envolvidos, e também pode apresentar alternativas à solução do problema considerado. 


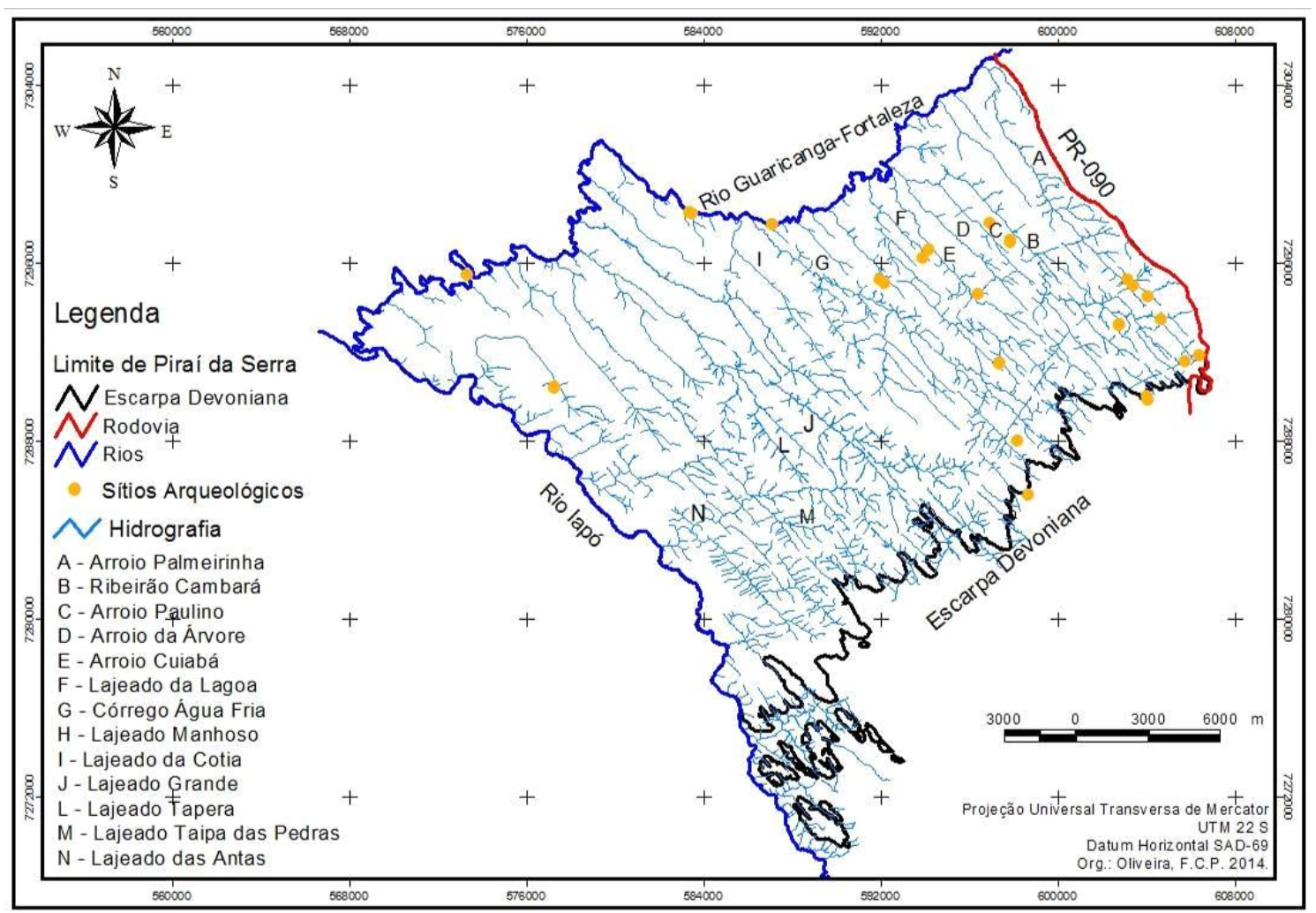

Figura 29: Mapa de hidrografia com os abrigos com pinturas rupestres em Piraí da Serra - Paraná. Fonte: UEPG, 2003; Pereira, 2009.

Desta forma, como afirma Barroso e Sousa (2007, p. 83) o SIG emprega "um banco de dados para armazenagem e recuperação de informações, o qual pode também ser aproveitado para gerar outras formas de análises de dados e facilitar a tomada de decisões". Os resultados são informações apresentadas na forma de tabelas e mapas os quais ainda podem ser manipulados de acordo com o objetivo, permitindo a obtenção de novos dados. O objetivo do SIG segundo Fitz (2004, p.23), é "coletar, armazenar, recuperar, manipular, visualizar e analisar dados espacialmente referenciados a um sistema de coordenadas conhecido".

Por meio do SIG, é possível a integração dos dados não espaciais e os espaciais, ao se alterar os dados dos abrigos no banco de dados (Tabela 01), simultaneamente eles terão sua localização espacial modificados nos mapas, pois são georreferenciados e os sistemas de gerenciamento de banco de dados do SIG possuem a topologia que compreende um arquivo com um modelo matemático que une os dados espaciais ao banco de dados numéricos ou semânticos. 
Segundo estudos de Proença (2010); Schmitz e Novasco (2011); Rogge e Beber (2013), pode-se perceber que são inúmeras as aplicações e as contribuições do SIG para as pesquisas arqueológicas. Como o SIG é uma tecnologia interdisciplinar e permite a convergência de diversos conteúdos científicos para o estudo de diferentes questões ambientais e culturais, é essencial que o pesquisador procure fontes de informação confiável e transforme adequadamente os conceitos de sua disciplina em representações computacionais, possibilitando a inserção e a manipulação desses dados juntamente com os dados espaciais.

Conforme a Tabela 01 , com os atributos dos sítios arqueológicos com pinturas rupestres, preenchida até o momento, consta o identificador numérico de cada ponto (ID), respectivo nome de cada abrigo representado por esses pontos, às coordenadas em UTM (SAD-69, Zona 22S) X e Y, a tradição arqueológica a que cada abrigo representa (Tradição Planalto ou Geométrica), o município que se localizam e a elevação de cada um dos pontos espacializados na área.

Este banco de dados teve como dados de entrada as coordenadas obtidas em campo com o receptor GPS (Global Positioning System), as quais representam espacialmente os abrigos com pinturas rupestres em Piraí da Serra, sendo estes, portanto, dados espaciais. Sendo os dados não espaciais os atributos contendo as características referentes a cada abrigo: ID, nome do abrigo, tradição arqueológica, elevação e o município ao qual pertencem.

As tecnologias de detecção remota e processamento digital de imagens aliados a confecção do banco de dados geográficos facilitaram enormemente as representações dos abrigos com pinturas rupestres da área de estudo. As técnicas de quantificação de padrões espaciais avançaram sobremaneira, o que tem permitido a comparação entre diferentes paisagens por meio da identificação de suas diferenças estruturais (ROSA, 2005). 
Tabela 01: Dados espaciais e não espaciais relacionados aos abrigos areníticos da Formação Furnas com pinturas rupestres da região de Piraí da Serra - Paraná.

\begin{tabular}{|c|c|c|c|c|c|}
\hline Nome dos Abrigos & $\begin{array}{l}\text { Coordenada } \\
\mathrm{X}\end{array}$ & $\underset{Y}{\text { Coordenada }}$ & Elevação & $\begin{array}{l}\text { Tradição } \\
\text { Rupestre }\end{array}$ & $\begin{array}{l}\text { Município } \\
\text { do Paraná }\end{array}$ \\
\hline 1. Cachoeira & 599.047 & 7.293 .66 & $1156 \mathrm{~m}$ & Geométrica & Piraí do Sul \\
\hline $\begin{array}{l}\text { 2. Cachoeira Canyon do Arroio } \\
\text { Palmeirinha }\end{array}$ & 597.539 & 7.295 .458 & $1054 \mathrm{~m}$ & *em análise & Piraí do Sul \\
\hline 3. Chapadinha I & 598.423 & 7.294 .640 & $1090 \mathrm{~m}$ & Planalto & Piraí do Sul \\
\hline 4. Chapadinha II & 597.809 & 7.295 .115 & $1070 \mathrm{~m}$ & Planalto & Piraí do Sul \\
\hline 5. Cuiacá I & 588.559 & 7.296 .791 & $978 \mathrm{~m}$ & Planalto & Piraí do Sul \\
\hline 6. Cuiacá II & 588.298 & 7.296422 & $1015 \mathrm{~m}$ & Planalto & Piraí do Sul \\
\hline 7. Fazenda das Cavernas 1 & 591.743 & 7.291 .710 & $1130 \mathrm{~m}$ & Planalto & Piraí do Sul \\
\hline 8. Fazenda das Cavernas 2 & 591.787 & 7.291 .689 & $1134 \mathrm{~m}$ & Planalto & Piraí do Sul \\
\hline 9. Guaricanga I & 581.494 & 7.297 .924 & $891 \mathrm{~m}$ & Planalto & Piraí do Sul \\
\hline 10. Guaricanga II & 581.520 & 7.297 .960 & $862 \mathrm{~m}$ & Planalto & Piraí do Sul \\
\hline 11. Paulino I & 591.346 & 7.297 .991 & $1002 \mathrm{~m}$ & Planalto & Piraí do Sul \\
\hline 12. Paulino II & 592.256 & 7.297.216 & $990 \mathrm{~m}$ & Planalto & Piraí do Sul \\
\hline 13. Paulino III & 592.266 & 7.297 .143 & $1006 \mathrm{~m}$ & Planalto & Piraí do Sul \\
\hline 14. Santa Rita I & 597.179 & 7.293 .424 & $1139 m$ & Geométrica & Piraí do Sul \\
\hline 15. Santa Rita II & 597.194 & 7.293 .436 & $1126 \mathrm{~m}$ & Geométrica & Piraí do Sul \\
\hline 16. São José da Lagoa I & 586.348 & 7.295 .440 & $1040 \mathrm{~m}$ & Planalto & Piraí do Sul \\
\hline 17. São José da Lagoa II & 586.564 & 7.295 .288 & $1039 \mathrm{~m}$ & Planalto & Piraí do Sul \\
\hline 18. Serra do Piraí 1 & 600.821 & 7.292 .031 & $1234 \mathrm{~m}$ & Planalto & Piraí do Sul \\
\hline 19. Serra do Piraí 2 & 600.165 & 7.291 .756 & $1223 \mathrm{~m}$ & Planalto & Piraí do Sul \\
\hline 20. Tarumã & 590.774 & 7.294 .792 & & *em análise & Piraí do Sul \\
\hline 21. Silvano & 592.557 & 7.288 .186 & $1232 \mathrm{~m}$ & *em análise & Piraí do Sul \\
\hline 22. Vitão & 593.071 & 7.285 .759 & & *em análise & Piraí do Sul \\
\hline 23. PS-415 & 598.460 & 7.290 .058 & $1148 \mathrm{~m}$ & Geométrica & Piraí do Sul \\
\hline 24. PS-421 & 598.442 & 7.290 .188 & $1157 \mathrm{~m}$ & Geométrica & Piraí do Sul \\
\hline 25. Cachoeira Bico do Pato 1 & 577.898 & 7.298 .409 & $822 \mathrm{~m}$ & Planalto & Tibagi \\
\hline 26. Cachoeira Bico do Pato 2 & 577.746 & 7.298 .498 & $817 \mathrm{~m}$ & Planalto & Tibagi \\
\hline 27. Cachoeira Bico do Pato 3 & 577.749 & 7.298 .484 & $827 \mathrm{~m}$ & Planalto & Tibagi \\
\hline
\end{tabular}


28. Casa de Pedra A

29. Cada de Pedra B

30. Ponte Alta
571.655

571.659

567.739

\begin{abstract}
7.290 .622
$901 \mathrm{~m}$

7.290 .614

$902 \mathrm{~m}$
\end{abstract}

7.295 .687
Planalto

Planalto

Planalto
Tibagi

Tibagi

Tibagi

\section{CONSIDERAÇÕES FINAIS}

O patrimônio arqueológico de Piraí da Serra constitui uma possibilidade notável para o desenvolvimento de pesquisas científicas uma vez que várias estratégias de apropriação da paisagem pelos grupos pré-coloniais podem ser analisadas através dos sítios arqueológicos. O estudo arqueológico junto com os dados históricos, geológicos, geográficos e paleoecológicos possibilitam uma visão bastante ampla das mudanças e transformações do meio físico num passado onde a ação antrópica já iniciava e acelerava processos de modificação da paisagem.

As pinturas rupestres representam parte do universo simbólico de um determinado grupo cultural que ocupou certa região, vestígios importantes de sua passagem e morada. Os diferentes estilos e técnicas empregadas nas pinturas rupestres mostram a diversidade e a riqueza na representação do imaginário dos povos pré-coloniais que ocuparam o território paranaense, que contrasta com o termo "povos primitivos", referindo-se aqui como sendo os primeiros povos dando, portanto, um sentido apenas temporal ao termo.

O estudo das pinturas rupestres, juntamente com estudos de outros vestígios arqueológicos contextualizados, pode colaborar na melhor compreensão de como o território paranaense foi ocupado e manejado.

A análise de dados geográficos na região de Piraí da Serra permitiu considerar que o tipo de suporte e a estrutura da rocha são elementos importantes na caracterização do sítio arqueológico com pinturas rupestres.

Por meio do SIG obteve-se um desenvolvimento sistematizado do trabalho pela organização dos dados e assim uma fácil visualização destas informações, além do cruzamento destes. Utilizando o software ArcView 3.2 percebeu-se que é um programa pertinente para a elaboração de um SIG, pois é de fácil compreensão e possui as interfaces necessárias para a entrada, armazenamento, manipulação, possíveis modificações e atualizações dos dados espaciais e não espaciais. Uma 
vez que a utilização do banco de dados pode servir para buscas e estudos no campo do turismo, trazendo respostas rápidas e organizadas ao usuário sobre as características de cada abrigo arenítico e quais podem ser visitados por uma peculiaridade específica.

Até o momento os trinta sítios arqueológicos espacializados possuem poucas informações contextualizadas, e com um maior detalhamento dos estudos talvez seja possível definir territórios e até mesmo entender a complexidade cultural dos diversos povos que habitaram a região.

É de extrema importância que se faça uma adequada gestão do patrimônio arqueológico entre os proprietários das fazendas de Piraí da Serra em convênio com o IPHAN, órgão federal responsável pela gestão desse patrimônio.

O estudo dos abrigos com pinturas rupestres da região pesquisada revela em vários casos forte degradação resultante de ação antrópica (fogo, depredação) ou natural (intemperismo das paredes rochosas, crescimento de organismos). Fato esse que torna imprescindível um número maior de estudos que viabilizem a divulgação do conhecimento arqueológico e paleoambiental para a população residente em Piraí da Serra e dos municípios que compõe essa região, o qual apresenta vestígios arqueológicos: Castro, Piraí do Sul e Tibagi, para que tenham consciência de preservar esse rico patrimônio arqueológico.

\section{REFERÊNCIAS}

BARROSO, H. G.; SOUSA, A. P. Áreas potenciais para a aqüicultura sustentável na bacia do rio Itapecuru: bases para o planejamento com uso do Sistema de Informação Geográfica. Revista Brasileira de Engenharia de Pesca, v. 2, n. 1, p.80-102, janeiro de 2007. Disponível em: http://ppg.revistas.uema.br/index.php/REPESCA/article/viewFile/36/32. Acesso em: 29 de abril de 2014.

FITZ, P. R. Geoprocessamento sem complicação. São Paulo: Oficina de Textos, 160p. 2008.

JORGE, M.; PROUS, A.; RIBEIRO, L. Brasil rupestre: a arte pré-histórica brasileira. Curitiba: Zencrane Livros, 272 p. 2007. 
KÖENE, R. Análise dos fatores condicionantes da estrutura do relevo na região de Piraí da Serra - Paraná. 70f. Trabalho de Conclusão de Curso (Geografia) Universidade Estadual de Ponta Grossa, Ponta Grossa. 2009.

LINKE, V. Paisagens dos sítios de pintura rupestre da região de DiamantinaMG. 2008. Dissertação de Mestrado (Geografia) - Universidade Federal de Minas Gerais, Belo Horizonte. 2008. Disponível em: http://www.bibliotecadigital.ufmg.br/dspace/handle/1843/MPBB-7ELPUK Acesso em 25 de janeiro de 2014.

MELO, M. S.; MATIAS, L. F.; GUIMARÃES, G. B.; CRUZ, G. C. F.; BARBOLA, I. F.; GEALH, A. M.; MORO, R. S.; AYUB, C. L. S. C.; MORO, P. G.; MOREIRA, J. C. Piraí da Serra - Proposta de nova Unidade De Conservação nos Campos Gerais do Paraná. Publicatio UEPG: Ciências Biológicas e da Saúde, Ponta Grossa, v. 10, n. 3 , p. 85-94, setembro/dezembro de 2004. Disponível em: http://www.revistas2.uepg.br/index.php/biologica/article/view/404/407. Acesso em: 29 de abril de 2014.

MINEROPAR - Minerais do Paraná. Cartas Geológicas do Estado do Paraná. Curitiba. 2006. Folha Telêmaco Borba. Escala 1:250.000. Disponível em: </MapasPDF/Geologocos/telemaco_borba.PDF.>. Acesso em: 01março 2013.

MOCHIUTTI, N. F. Os valores da geodiversidade da região de Piraí da Serra, Campos Gerais do Paraná. 128f. Trabalho de Conclusão de Curso (Geografia) Universidade Estadual de Ponta Grossa, Ponta Grossa. 2009.

OLIVEIRA, F.C.P. Abrigos com pinturas rupestres em Piraí da Serra - Paraná: Uma abordagem geoarqueológica. 325f. Dissertação (Mestrado em Geografia) Setor de Ciências da Terra, Universidade Federal do Paraná, Curitiba. 2014.

PARELLADA, C.I. Arqueologia dos Campos Gerais. In: Melo, M. S.; Moro. R. S.; Guimarães, G. B. Patrimônio Natural dos Campos Gerais do Paraná. Ponta Grossa: Editora UEPG, p. 163-170. 2007.

Revisão dos sítios arqueológicos com mais de seis mil anos BP no Paraná: discussões geoarqueológicas. FUMDHAMentos, Fundação Museu do Homem Americano, Piauí, v.7, p.117-135, 2008. Disponível em: http://www.fumdham.org.br/fumdhamentos7/artigos/7\%20Parellada.pdf. Acesso em: 29 de abril de 2014. 
Arte rupestre no Paraná. Revista científica FAP, Curitiba, v.4, n.1 p.1-25, janeiro/junho. 2009. Disponível em: http://www.fap.pr.gov.br/arquivos/File/Arquivos2009/Pesquisa/Rev_cientifica4/artigo_ Claudia_Parellada_1.pdf. Acesso em: 29 de abril de 2014.

. Arqueologia do vale do rio Piquiri, Paraná: paisagens, memórias e transformações. Revista Memorare, Unisul, Tubarão, v. 1, n. 1, p. 24-42, 2013. Disponível

em: https://www.academia.edu/6846945/Arqueologia_do_vale_do_rio_Piquiri_Parana_pa isagens_memorias_e_transformacoes_Revista_Memorare_UNISUL_2013_v.1_n.1_ p.24-42. Acesso em: 29 de abril de 2014.

Arqueóloga do Museu Paranaense registra descoberta histórica de pintura rupestre. Agência de Notícias do Paraná, Reportagem do TV É-Paraná. Matéria publicada em 26/02/2014 as 14:20 horas. Entrevista. Disponível em: http://www.aen.pr.gov.br/modules/noticias/article.php?storyid=79245\&tit=TVeParana-registra-descoberta-historica-de-pintura-rupestre http://www.museuparanaense.pr.gov.br/modules/noticias/article.php?storyid=86\&tit= Arqueologa-do-Museu-Paranaense-registra-descoberta-historica-de-pintura-rupestre Acesso em 15 de maio de 2014.

PARELLADA, C. I.; OLIVEIRA, F. C. P.; SCLVILZK, E. S. As pinturas rupestres do abrigo São José da Lagoa 2, Piraí do Sul, Paraná, Brasil. Anais do X Simpósio Internacional de Arte Rupestre e V Reunião da Associação de Arte Rupestre Teresina - Piauí, resumo, 2014. Disponível em: http://www.arqueologiabrasilis.com.br/wp-

content/uploads/sites_dinamicos/x_siar_2014/X_SIAR_V_ABAR-digital.pdf . Acesso em: 02/09/2014.

PEREIRA, F. C; MELO, M. S.; PARELLADA, C. I. Patrimônio Arqueológico da região de Piraí da Serra - Paraná. Anais do XVII EAIC - 19 a 22 de novembro de 2008. Disponível em: http://www.ppg.uem.br/docs/pes/eaic/XVII_EAIC/index.html. Acesso em: 20 de janeiro de 2014.

PEREIRA, F. C. As pinturas rupestres na região de Piraí da Serra - Paraná. 125f. Trabalho de Conclusão de Curso (Geografia) - Universidade Estadual de Ponta Grossa, Ponta Grossa. 2009.

PROENÇA, A. L. reconhecimento arqueológico na região do Catimbau: prospecção, geoprocessamento e estratigrafias no contexto arqueológico. Revista de Geografia. 
Recife: UFPE - DCG/NAPA, v. especial VIII SINAGEO, n. 2, p. 288-301, Setembro de $2010 . \quad$ Disponível em: http://www.revista.ufpe.br/revistageografia/index.php/revista/article/viewFile/362/326. Acesso em: 29 de abril de 2014.

PROUS, A. Arqueologia Brasileira. Brasília, Distrito Federal: Editora Universidade de Brasília, 605 p. 1992.

PROUS, A.; BAETA, A.; RUBBIOLI, E. O patrimônio arqueológico da região de Matozinhos: conhecer para proteger. Belo Horizonte: Ed. do autor, 132p. 2003.

RETZLAF, J. G.; STIPP, N. A. F.; ARCHELA, E. Breve síntese geológica e geomorfológica da área do parque estadual do Guartelá no estado do Paraná. Geografia, v. 15, n. 1, jan./jun. 2006 - Universidade Estadual de Londrina, Departamento de Geociências. Disponível em: http://www.uel.br/revistas/uel/index.php/geografia/article/download/6655/6004. Acesso em 29 de abril de 2014.

ROGGE, J. H.; BEBER, M. V. Arqueologia das estruturas subterrâneas do sul do Brasil. Revista Tempos Acadêmicos, Dossiê Arqueologia Pré-Histórica, no 11, 2013, Criciúma, Santa Catarina. Disponível em: http://periodicos.unesc.net/index.php/historia/article/download/1131/1096. Acesso em: 29 de abril de 2014.

ROSA, R. Geotecnologias na geografia aplicada. Revista do Departamento de Geografia, n.16, p.81-90, 2005. Disponível em: http://www.geografia.fflch.usp.br/publicacoes/RDG/RDG_16/Roberto_Rosa.pdf. Acesso em: 29 de abril de 2014.

SCHMITZ, P. I., NOVASCO, R. V. Arqueologia no planalto: o uso do SIG na aplicação de análises espaciais dos sítios arqueológicos da localidade Boa Parada, Município de São José do Cerrito, SC. Revista do Museu de Arqueologia e Etnologia, São Paulo, n. 21, p. 167-183, 2011. Disponível em: http://www.mae.usp.br/wp-content/uploads/2013/07/167-183-Novasco.pdf. Acesso em: 29 de abril de 2014.

SILVA, A. C.; MELO, M. S.; PARELLADA, C. I. Pinturas rupestres em abrigo sob rocha no sumidouro do rio Quebra-Perna, Ponta Grossa, Paraná. Publicatio UEPG: Ciências Exatas e da Terra, Ciências Agrárias e Engenharias, Ponta Grossa, v. 12, n.1, p. 23-31, abril de 2006. Disponível em: 
http://www.revistas2.uepg.br/index.php/exatas/article/viewFile/861/744. Acesso em 29 de abril de 2014.

SILVA, A. C.; PARELlADA, C. I.; MELO, M. S. Pinturas rupestres do sítio arqueológico abrigo Usina São Jorge, Ponta Grossa, Paraná. Publicatio UEPG: Ciências Exatas e da Terra, Ciências Agrárias e Engenharias, Ponta Grossa, Ponta Grossa, v. 13, n. 1, p. 25-33, abril de 2007. Disponível em: http://www.revistas2.uepg.br/index.php/exatas/article/view/876. Acesso em 29 de abril de 2014.

UEPG - Universidade Estadual de Ponta Grossa. Caracterização do Patrimônio Natural dos Campos Gerais do Paraná. Relatório UEPG, p 70-76,85. 2003. 